\title{
MAKNA PERBUATAN HUKUM PUBLIK OLEH BADAN ATAU \\ PEJABAT ADMINISTRASI NEGARA YANG MELANGGAR (SUATU TINJAUAN YURIDIS MENURUT HUKUM ADMINISTRASI NEGARA)
}

\author{
Agus Budi Susilo \\ Pengadilan Tata Usaha Negara Yogyakarta
}

\begin{abstract}
Abstrak
Badan atau Pejabat administrasi negara (jabatan administrasi negara) mempunyai wewenang yang luas dalam melaksanakan urusan pemerintahan (eksekutif). Dengan wewenang yang luas ini cenderung untuk disalahgunakan sehingga menimbulkan kerugian dan ketidakadilan di pihak masyarakat, oleh karena itu harus ada lembaga lain yang mengontrolnya. Berdasarkan teori trias politika lembaga eksekutif secara politis dikontrol oleh lembaga legislatif dan secara yuridis dikontrol oleh lembaga yudikatif, karena pejabat administrasi negara menjalankan fungsi eksekutif maka lembaga yudikatif yang mengontrol secara yuridis adalah pengadilan administrasi negara. Kontrol yuridis oleh pengadilan administrasi negara saat ini berdasarkan Undang-undang Nomor 51 Tahun 2009 (perubahan kedua) dan Undang-undang Nomor 9 Tahun 2004 (perubahan pertama) yang merevisi Undang-Undang Nomor 5 Tahun 1986 Tentang PTUN hanya dalam hal ketetapan administrasi (beschikking) yang dikeluarkan oleh badan atau pejabat administrasi negara saja, padahal secara philosofis kompetensi absolut pengadilan administrasi negara adalah menyelesaikan sengketa administrasi negara dalam arti luas. Oleh karenanya berdasarkan pandangan futuristik perlu ditelaah lebih lanjut undangundang tersebut untuk direvisi terutama mengenai makna sengketa administrasi negara berupa perbuatan hukum publik oleh jabatan administrasi negara yang melanggar hukum. Semua ini tiada lain bertujuan untuk mereposisi kembali hakikat penegakan hukum administrasi oleh pengadilan administrasi negara dan menyederhanakan (effisiensi dan effektifitas) semua penyelesaian sengketa administrasi negara yang selama ini dilakukan oleh peradilan umum (misalnya sengketa administrasi negara mengenai HAKI dan ketenagakerjaan) dan peradilan khusus (misalnya sengketa pajak) menjadi kewenangan absolut pengadilan administrasi negara.
\end{abstract}

Kata Kunci: perbuatan hukum publik, badan administrasi negara, melanggar hukum.

\begin{abstract}
Agency or Officer in the state administration (office of the state administration) has broad authority in conducting the affairs of government (executive). With this broad authority tend to abuse that caused harm and injustice in the society, therefore there must be other institutions that control it. Based on the theory of triad politics of the executive is politically controlled by the legislative and juridical institutions controlled by the judiciary, because the state administration officials running the executive functions that control the judiciary is legally the state administrative court. Judicial control by the state administrative court is currently under Law No. 51 of 2009 (second amendment) and Law No. 9 of 2004 (first change) is revising the Law No. 5 of 1986 concerning the Adminis-
\end{abstract}


trative Court only in the case of administrative provisions (beschikking) issued by the agency or official of the state administration alone, whereas the absolute competence philosofis state administrative court is to settle disputes in a broad sense the state administration. Therefore based views need to be explored further futuristic law to be revised, especially about the meaning of the state administrative disputes in the form of legal action by the office of public administration in violation of state law. All this is nothing else aims to reposition the nature of administrative enforcement by the courts and simplify state administration (efficiency and effectiveness) of all state administrative dispute resolution has been done by a civil court (for example, state administrative disputes regarding intellectual property rights and labor) and special courts (eg tax disputes) to the absolute authority of the state administrative court.

Keywords: legal acts of public, state administration bodies, violate the law.

\section{PENDAHULUAN}

Berbicara mengenai makna perbuatan hukum publik oleh badan atau pejabat administrasi negara yang melanggar hukum ditinjau dari sudut hukum administrasi negara, maka penulis mencoba memulai untuk mengurai apa arti kata dari "makna" itu sendiri. "Makna" menurut W.J.S. Poerwadarminta sepadan dengan kata "arti" dan "maksud" (W.J.S. Poerwadarminta, 2002;624) "Arti” itu sendiri mempunyai pengertian maksud yang terkandung dalam kata atau juga kiasan dari kata "guna", "faedah", atau "kepentingan" (W.J.S. Poerwadarminta, 2002:58). Adapun "maksud" sama halnya dengan "yang dikehendaki", "tujuan", "niat yang tertentu", "sesuatu yang terkandung dalam kalimat" (W.J.S. Poerwadarminta, 2002; 625). Kaitannya dengan masalah yang akan penulis kaji yaitu yang berkaitan dengan makna perbuatan hukum publik oleh badan atau pejabat administrasi yang melanggar hukum, maka makna disini sama dengan mencoba menelusuri arti dan maksud dari perbuatan hukum publik oleh badan atau pejabat administrasi negara yang melanggar hukum itu sendiri dengan menggunakan pisau analisisnya teoriteori yang ada dalam hukum administrasi negara.

Setelah menguraikan pengertian dari kata "makna", maka perlu pula di uraikan mengenai pengertian "perbuatan hukum publik oleh badan atau pejabat administrasi yang melanggar hukum". "Perbuatan hukum publik" yang dimaksud dalam hal ini adalah perbuatan hukum publik yang dilakukan oleh badan atau pejabat administrasi negara. Secara teoritis bahwa perbuatan hukum publik mempunyai dua pengertian, yaitu perbuatan hukum publik bersegi satu (vertikal) dan perbuatan hukum publik bersegi dua 
(horisontal) menurut hukum administrasi negara. Perbuatan hukum publik bersegi satu ini secara teoritis dikenal dengan keputusan administrasi negara. Menurut Prajudi Atmosudirdjo sendiri, Keputusan-keputusan (beslissingen) dari pada badan atau pejabat administrasi negara terdiri dari: penetapan (beschikking), rencana (plan), norma penjabaran (concrete normgeving), dan legislasi-semu (pseudo-wetgeving) atau peraturan-peraturan kebijakan (beleids regel) (Prajudi Atmosudirdjo, 1994;93). Menurut Prajudi Atmosudirdjo sendiri mengenai empat bentuk keputusan ini ; pertama, penetapan ini merupakan perbuatan hukum yang sepihak (eenzijdig), bersifat administrasi negara artinya realisasi dari pada ketentuan undang-undang secara nyata, kasual (menurut kasus-kasus tertentu), dan individual; kedua, rencana termasuk salah satu bentuk perbuatan hukum sepihak di bidang Hukum Administrasi yang mencipta hubungan hukum (yang mengikat) antara Penguasa dan para Warga Masyarakat, maka rencana adalah seperangkat tindakan-tindakan yang terpadu, dengan tujuan agar tercipta suatu keadaan yang tertib bilamana tindakan-tindakan tersebut telah selesai direalisasikan, misalnya: Rencana Tata Hutan (penentuan margasatwa dan hutan lindung); ketiga, norma penjabaran adalah suatu perbuatan hukum oleh pejabat administrasi untuk membuat agar suatu ketentuan undang-undang mempunyai isi yang konkret, praktis, dan dapat diterapkan menurut keadaan waktu dan tempat, misalnya : di bidang lalu-lintas (pemasangan dari ramburambu lalu-lintas, penunjukan tempat parkir, dan anjuran memakai helm bagi pengendara sepeda motor); keempat, pseudo-wetgeving adalah penciptaan dari aturan-aturan hukum oleh pejabat administrasi yang berwenang dan sebenarnya dimaksudkan sebagai garisgaris pedoman (richtlijnen) pelaksanaan kebijaksanaan (policy) untuk menjalankan suatu ketentuan undangundang, akan tetapi dipublikasikan secara luas (Prajudi Atmosudirdjo, 1994:94-103).

Pendapat tersebut sama halnya dengan pendapat S.F. Marbun yang merumuskan keputusan administrasi negara sebagai berikut (S.F. Marbun, 2001:219-220). Keputusan ialah perbuatan hukum publik bersegi satu yang dilakukan oleh alat pemerintahan (dalam arti sempit) berdasarkan suatu kekuasaan atau wewenang istimewa dengan maksud terjadinya perubahan dalam hubungan hukum. Selanjutnya beliaupun menjelaskan bahwa pengertian keputusan administrasi negara tersebut bersifat netral. Maksudnya, pengertian 
tersebut tercakup di dalamnya pengertian keputusan dalam arti konkritindividual (beschikking) dan keputusan dalam arti (umum-abstrak) atau regeling. Dalam arti yang umum abstrak inilah masuk pula didalamnya rencana (plan), norma penjabaran (concrete normgeving), dan legislasi-semu (pseudowetgeving) atau peraturan-peraturan kebijakan (beleids regel).

Lain halnya dengan perbuatan hukum publik bersegi dua, dimana perbuatan pejabat administrasi negara yang demikian masih ada silang pendapat tentang keberadaannya. Bahkan dalam perkembangannya ada yang berpendapat bahwa selain perbuatan hukum bersegi satu dan dua, adapula perbuatan hukum publik bersegi banyak (meerziydig) misalnya: pembuatan Surat Ketetapan Bersama yang dilakukan lebih dari dua pejabat administrasi dari instansi yang berbeda. Meskipun demikian penulis tidak sependapat dengan hal tersebut, karena meskipun Surat Ketetapan Bersama dilakukan lebih dari dua pejabat dari instansi yang berbeda tetapi sifatnya masih horisontal masih masuk kriteria perbuatan hukum publik yang bersegi dua. Berkenaan dengan perbuatan hukum publik tersebut penulis sependapat dengan Rustini Wiriaatmadja, yang berpendapat (Rustini Wiriaatmadja, 1992:112): Semua perbuatan

pemerintahan yang berdasar-kan hukum publik sejauh perbuatan itu dilakukan oleh aparat Pemerintah selaku penguasa, merupakan perbuatan hukum bersegi satu, sebab kedudukan antara penguasa dengan yang dikuasai tidak sejajar, akan tetapi lebih merupakan hubungan hierarkhis. Sedangkan perbuatan hukum yang berdasarkan hukum publik yang dilakukan oleh aparat Pemerintah selaku organ dari Pemerintah sebagai badan hukum (bestuurorganen) mungkin sekali bersifat segi dua maupun segi satu. Sebenarnya dalam hal ini perbuatan tersebut merupakan pengkhususan dari hukum perdata (privat).

Berbeda halnya dengan Ateng Syafrudin (Wawancara Penulis dengan Ateng Syafrudin tanggal 19 Desember 2003 ketika sedang melakukan penelitian), beliau berpendapat bahwa perbuatan hukum publik yang dilakukan oleh badan atau pejabat administrasi negara bukan hanya yang sifatnya tertulis saja, melainkan perbuatan hukum publik tidak tertulis. Maksudnya selain perbuatan hukum publik tertulis sepanjang badan atau pejabat administrasi negara melakukan tindakan berdasarkan hukum publik dapat dikategorikan sebagai pengertian perbuatan hukum publik yang dapat dipertanggung jawabkan di pengadilan administrasi negara (PTUN). Misalnya : pembongkaran secara paksa rumah seseorang atau warga yang Administrasi Negara) 
menempati tanah yang dikuasai pemerintah daerah setempat berdasarkan perintah lisan oleh badan atau pejabat administrasi negara kepada bawahannya.

Contoh lain yang pernah terjadi adalah kasus (menyangkut politik) seperti pemberian izin Kongres PDI di Medan pada tahun 1997 serta pengesahan hasil Kongres tersebut oleh Menteri Dalam Negeri. Secara politis, Kongres tersebut sengaja diadakan untuk menjatuhkan kedudukan Megawati Soekarno Putri sebagai Ketua Umum PDI waktu itu. Dalam hal ini Megawati sulit untuk menggugat ke PTUN karena keputusan tersebut tidak dikeluarkan secara tertulis (Lintong Oloan Siahaan, 2000:41).

Meskipun pendapat tersebut dalam praktek masih banyak silang pendapat karena perbuatan hukum publik tidak tertulis sulit untuk dibuktikan di pengadilan administrasi negara (PTUN), tetapi penulis sependapat dengan Ateng Syafrudin sebagai suatu wacana ke depan nantinya bahwa perbuatan tersebut dapat diajukan ke pengadilan administrasi negara (PTUN) sepanjang dapat dibuktikan dalam persidangan dan hakim administrasi negara yang dapat menilai perbuatan hukum publik tersebut.

Bahkan pendapat yang lebih radikal lagi menyatakan bahwa sebaik- nya semua perkara perbuatan melanggar hukum oleh penguasa atau pemerintah (onrechmatige overheids daad) yang selama ini menjadi payung hukumnya adalah Pasal 1365 KUHPerdata dialihkan menjadi kompetensi peradilan administrasi negara (PTUN) dalam rangka effisiensi dan effektifitas serta mengintegrasikan semua sengketa yang berkenaan dengan perbuatan hukum oleh badan atau pejabat administrasi negara ketika memangku suatu jabatan yang melanggar hukum sebagaimana yang berlaku di Perancis tempat asal mula dibentuknya badan peradilan administrasi negara di bawah lembaga Conceil d'Etat.

\section{Makna "Melanggar Hukum" menurut Hukum Administrasi Negara}

Pengertian "melanggar hukum" disini penulis menggunakannya berdasarkan terjemahan dari istilah "onrechtmatige" yang lebih tepat diartikan demikian, dari pada diartikan "melawan hukum". Perlu penulis tambahkan bahwa pelanggaran hukum ini, bukan hanya melanggar hukum dalam arti tertulis saja melainkan juga hukum tidak tertulis.

Walaupun Pasal 53 ayat (2) Undang-undang Nomor 5 Tahun 1986 Jis Undang-Undang No. 9 Tahun 2004 dan Undang-undang Nomor 51 Tahun 2009 
memberi makna pelanggaran hukum juga dengan pengertian melanggar hukum tertulis (peraturan perundangundangan) dan melanggar asas-asas umum pemerintahan yang baik, oleh karenanya beberapa hakim administrasi negara menyatakan bahwa yang dimaksud onrechtmatige adalah badan atau pejabat administrasi negara dalam membuat suatu keputusan administrasi negara berbuat willekeur dan detorunement de pouvoir (Wawan-cara penulis dengan Imam Soebechi Direktur Tata Usaha Negara pada Mahkamah Agung R.I) tanggal 18 Februari 2004 ketika melakukan suatu penelitian dan saat ini beliau sudah menjadi Hakim Agung. Pada saat wawancara Undangundang ini masih menggunakan Undang-undang No. 5 Tahun 1986, Pasal 53 ayat (2) yang pada intinya menyatakan Keputusan TUN dapat dinyatakan batal atau tidak sah apabila: (a) bertentangan dengan peraturan perundang-undangan; (b)detorunement de pouvoir; (c). willekeur), tetapi penulis berpendapat hal ini tidaklah cukup diartikan demikian karena dirasakan masih terlalu sempit. Berpatokan bahwa hukum sangatlah abstrak atau banyak yang mendefinisikannya secara berbedabeda dan luas, maka penulis berpegangan bahwa hakim administrasi negara bebas menafsirkan arti pelanggaran hukum itu sendiri, karena dalam penulisan ini penulis lebih menekankan pada pembentukan hukum baru (rechtsvin-ding) dalam rangka penegakan hukum administrasi negara. Meskipun demiki-an, ada beberapa hakim administrasi negara yang dalam membuat per-timbangan hukum Putusan menyebutkan bahwa dibatalkannya keputusan administrasi negara karena bertentangan dengan salah satu sila dari Pancasila (Wawancara penulis dengan Agus Djunaedi Iskandar (Hakim Yustisial pada Mahkamah Agung R.I) tanggal 18 Februari 2004 ketika melakukan suatu penelitian). Hal yang demikian penulis sependapat karena Pancasila merupakan grundnorm (Bandingkan Soejadi, 1999; 120).

Perlunya penegakan hukum administrasi negara dalam konteks ini, menurut penulis karena sebagaimana diungkapkan oleh I Gde Pantja Astawa (I Gede Pantja Astawa dalam S.F. Marbun, et.al., 2001;309-310), bahwa sebagai konsekuensi dengan semakin meningkat pesat pembangunan di berbagai sektor/ bidang kehidupan, maka pemerintah dalam hal ini badan atau pejabat administrasi negara semakin aktif dan intensif ikut campur ke dalam berbagai segi kehidupan masyarakat. Oleh karenanya hukum administrasi negara berperan sangat dominan dan penting artinya sebagai 
landasan atau dasar pijakan bagi tindakan badan atau pejabat administrasi negara dalam rangka mewujudkan apa yang menjadi tugasnya yaitu menyelenggarakan service public.

Atas dasar kondisi faktual tersebut, untuk mencegah timbulnya ekses-ekses dari tindakan administrasi negara, maka dibutuhkan peranan hukum administrasi negara yang berfungsi secara normatif sebagai pengatur dan koridor pada saat beraksinya administrasi negara untuk merealisasikan kewenangan-kewenangan yang dimilikinya (Suprin Na'a, 2003;57).

Seperti halnya dalam praktek, banyak hakim administrasi negara masih memakai pola pikir yang kaku dalam menerapkan peraturan perundangundangan. Dalam keadaan yang demikian mengakibatkan implementasi penegakan hukum administrasi negara menjadi simpang siur dan berakibat tujuan keadilan, kepastian hukum, dan kemanfaatan jadi terasa sulit direalisasikan. Banyak sekali penyelesaian sengketa yang berkenaan dengan lintas kompetensi lembaga peradilan terjadi kontradiktif ketika memberi Putusan. Misalnya sengketa pertanahan, si A selaku Penggugat mengajukan gugatan ke pengadilan administrasi negara (PTUN) untuk dapat membatalkan sertifikat tanah yang dikeluarkan oleh Kepala Badan Pertanahan Nasional
(BPN), tetapi di lain pihak terhadap objek sengketa yang sama, sebelumnya telah ada putusan dari pengadilan negeri antara si A tersebut dengan si B mengenai kepemilikan dan dimenangkan oleh si A, tetapi pihak Tergugat (Kepala BPN) tidak mau membatalkan sertifikat atas nama B. Permasalahan dalam praktek, hakim administrasi negara jarang yang berani membuat suatu pertimbangan hukum dengan mengaitkan putusan dari pengadilan negeri sebagai dasar putusan bahwa telah terjadi perbuatan melanggar hukum oleh badan atau pejabat administrasi negara, yang terjadi sebaliknya bahkan putusan pengadilan administrasi negara (PTUN) menjungkir balikan putusan pengadilan negeri atau Mahkamah Agung yang telah in kracht van gewijsde. Hal ini terjadi karena pola pikir dan wawasan hakim pada peradilan administrasi negara (PTUN) yang masih terkotak-kotak dalam pembidangan antara hukum perdata dan hukum administrasi negara, sehingga tidak melihat hubungan hukum terutama mengenai arti kepentingan yang dirugikan antara keduanya bahkan melakukan suatu disparitas dalam penyelesaian sengketa terhadap kasus tersebut.

Dalam praktek mengenai hubungan hukum perdata dan hukum administrasi sudah ada Putusan Kasasi yang memberikan titik temu, yaitu 
Putusan Mahkamah Agung Republik Indonesia Nomor $88 \mathrm{~K} / \mathrm{TUN} / 1993$ Tanggal 7-9-1994. Pada Putusan ini dapatlah ditarik suatu kaidah hukum, yaitu :

Meskipun sengketa itu terjadi akibat dari adanya Surat Keputusan Pejabat, tetapi jika dalam perkara tersebut menyangkut pembuktian hak kepemilikan atas tanah, maka gugatan atas sengketa tersebut harus diajukan terlebih dahulu ke Peradilan Umum karena merupakan sengketa perdata.

Berdasarkan Putusan MA inilah, mekipun dalam sengketa tanah mempunyai dua titik singgung yaitu aspek keperdataan dan aspek administratif, maka kedua badan peradilan (peradilan umum dan peradilan administrasi negara) tersebut sama-sama memiliki kompetensi absolut. Hanya saja sebelum diajukan mengenai batal atau tidak sahnya prosedur penerbitan sertifikat tanah dari badan atau pejabat administrasi negara yang bersangkutan, terlebih dahulu mengenai kepemilikan (hak milik) diselesaikan dulu di Pengadilan Negeri. Setelah di putus oleh pengadilan negeri dan kemudian diajukan ke pengadilan administrasi negara (PTUN), maka hakim administrasi negara harus pula mempertimbangkan Putusan dari pengadilan negeri tadi terutama mengenai kepentingan pihak yang dirugikan.
Meskipun hal tersebut diatas dari sudut pandang kepastian hukum dapat saja dilakukan, tetapi terkadang dirasa sulit diterapkan terutama dalam hal batas tenggang waktu dalam hukum acara peradilan administrasi (vide Pasal 55 Undang-undang No. 9 Tahun 2004). Maka lebih adil kiranya apa yang ditentukan dalam Juklak M.A No.224/Td.TUN/X/1993 tanggal 14 Oktober 1993 khususnya butir V yang menyatakan : Kalau terjadi gugatan mengenai tanah diajukan ke Peradilan Umum dan Peradilan Tata Usaha Negara dalam waktu yang bersamaan, maka yang menjadi wewenang Peradilan Tata Usaha Negara hanya mengenai sertifikat tanahnya, apakah prosedur penerbitannya sudah sesuai dengan ketentuan perundang-undangan yang berlaku. Sedangkan mengenai soal kepemilikan adalah wewenang dari Peradilan Umum.

Jika terjadi sengketa pertanahan yang mempunyai dua titik singgung (hukum perdata dan hukum administrasi negara) maka dapat diajukan gugatan kedua lembaga peradilan yang mempunyai kompetensi absolut masingmasing, sehingga dalam penyelesaian sengketanya tidak perlu lagi menunggu putusan mengenai hak milik atau kepemilikan tanah tersebut milik siapa. Menurut hemat penulis, hal ini lebih mencerminkan asas keadilan.

Menanggapi aspek keperdataan 
dan aspek administratif terhadap suatu sengketa, penulis sepakat dengan pendapat I Gde Pantja Astawa yang menyatakan bahwa konsekuensi logis dari dilaksanakannya bestuurzorg oleh badan atau pejabat administrasi negara yang semakin luas dan semakin intensifnya negara ikut campur dalam segala segi kehidupan masyarakat, dalam kenyataannya menimbulkan gejala makin besarnya lapangan hukum administrasi negara dan makin kecilnya lapangan hukum privat (I Gde Pantja Astawa, dalam S.F. Marbun,et.al., 2001;297). Oleh karena itu, hakim administrasi negara tidak perlu ragu untuk menerapkan hukum yang berkenaan dengan suatu perkara yang didalamnya dapat dikategorikan lapangan hukum perdata sekaligus hukum administrasi negara.

Contoh lain adalah penerapan putusan pidana dari pengadilan negeri terhadap perkara diberhentikannya seorang aparatur kelurahan sebagai pegawai negeri oleh Bupati. Menurut penulis, hakim administrasi negara dapat mempertimbangkan Putusan oleh pengadilan negeri yang berkenaan dengan terbitnya suatu keputusan administrasi negara yang disengketakan di pengadilan administrasi negara (PTUN). Hal ini dikarenakan, di samping untuk terwujudnya suatu kepastian hukum juga sebagai kontrol yuridis terhadap badan atau pejabat administrasi negara yang dianggap melakukan suatu pelanggaran hukum (baik hukum pidana maupun hukum administrasinegara).

Masalah yang serupa (seperti halnya sengketa pertanahan diatas), bila keduanya diajukan dalam waktu yang bersamaan yaitu proses pidana melalui pengadilan negeri dan gugatan melalui pengadilan administrasi negara (PTUN). Meskipun hal ini dapat dilakukan, tetapi dari segi berproses berperkara para pihak harus menempuh jalan panjang untuk mendapatkan kebenaran dan keadilan. Menurut penulis, dalam penyelesaian perkara yang demikian Hakim administrasi negara sedapat mungkin mencapai pada titik keadilan sekaligus kebenaran materiil.

Melihat permasalahan penggabungan kasus-kasus tersebut (perkara perdata dan sengketa administrasi negara maupun perkara pidana dan sengketa administrasi negara), menurut Philipus M. Hadjon (Philipus M.Hadjon, 1997;7) dalam rangka meningkatkan perlindungan hukum bagi rakyat di Indonesia perlu dikaji untuk pengembangan hukum administrasi negara di Indonesia, sehingga dimungkinkan adanya integrasi badan-badan pengadilan dalam hal penyelesaian kasus-kasus yang dimaksud. Beliau mencontohkan KUHAP yang mengatur penggabungan perkara Agus Budi Susilo 
pidana dan perdata, sehingga ada kemungkinan sehingga ada kemungkinan penggabungan dengan sengketa administrasi negara.

Perlu penulis kemukakan pula di sini, bahwa pengertian dari perbuatan melanggar hukum oleh badan atau pejabat administrasi negara bukanlah seperti apa yang dimaksud dalam Pasal 7A dan 7B ayat (1) UUD 1945. Pengertian dalam ketentuan tersebut adalah dikatakan bahwa Presiden (selaku Kepala Pemerintahan atau Pejabat Administrasi Negara) dianggap telah melakukan pelanggaran hukum apabila melakukan pengkhianatan terhadap negara, korupsi, penyuapan, tindak pidana berat lainnya ataupun perbuatan tercela. Terlihat bahwa pelanggaran hukum yang dimaksud adalah bersifat tindak pidana, meskipun ada istilah perbuatan tercela yang masih bersifat umum.

Bukan hal yang tidak mungkin terjadi pengertian perbuatan melanggar hukum oleh Presiden menurut Pasal 7A dan 7B ayat (1) UUD 1945 yang dimaksud, bila dikaitkan dengan perbuatan melanggar hukum oleh badan atau pejabat administrasi negara yang penulis kaji dalam tulisan ini, penulis berpendapat bahwa bila Presiden selaku pejabat administrasi negara tertinggi tidak menjalankan putusan pengadilan administrasi negara (PTUN) yang sudah in kracht van gewijsde dapat dikatakan telah melakukan suatu perbuatan tercela, yaitu tidak mematuhi hukum dengan melecehkan putusan lembaga peradilan.

\section{Makna Perbuatan Hukum Publik oleh Badan atau Pejabat Administrasi Negara yang Melanggar Hukum Tidak Tertulis}

Makna lain dari pengertian pelanggaran hukum ini, penulis berpendapat bahwa pelanggaran terhadap asas atau norma hukum publik secara umum dan hukum adat atau hukum kebiasaan dapat pula dijadikan sebagai tolok ukur pengertian perbuatan melanggar hukum oleh badan atau pejabat administrasi negara.

Memang masih terlalu abstrak dan sumir untuk menjadikan asas atau norma hukum publik secara umum sebagai tolok ukur perbuatan melanggar hukum oleh badan atau pejabat administrasi negara. Selain dikarenakan belum adanya kesepakatan yang secara komprehensif mengenai arti asas atau norma hukum publik itu sendiri terutama dalam hal penegakan hukum administrasi negara, juga untuk me-nerapkan dalam praktek masih terasa sulit sebab untuk mengukur kapan mendahulukan keadilan daripada kepastian hukum atau sebaliknya. 
Untuk mengetahui maksud asas dan norma hukum publik ini, penulis berangkat dari pengertian asas dan norma itu sendiri. Menurut W.J.S. Poerwadarminta, pengertian asas adalah: (1)Dasar, alas, pondamen; misalnya : batu yang baik untuk asas rumah; (2)Sesuatu kebenaran yang menjadi pokok atau tumpuan berpikir (berpendapat dan sebagainya); misalnya : bertentangan dengan asas-asas hukum pidana, pada asasnya saya setuju dengan usul saudara; (3)Cita-cita yang menjadi dasar (perkumpulan, negara dan sebagainya); misalnya : membicarakan asas dan tujuan perserikatan (W.J.S. Poerwadarminta, 2002; 60-61).

Beranjak dari pengertian asas tersebut, Sri Soemantri berpendapat bahwa arti nomor dualah yang lebih tepat dalam kaitannya dengan hukum, karena dengan demikian akan ditemukan kebenaran yang menjadi pokok dasar atau tumpuan berpikir atau berpendapat, misalnya hukum keperdataan, hukum kepidanaan, hukum tata negara dan hukum administrasi negara atau hukum tata pemerintahan (Sri Soemantri, 1995;136).

Rumusan lain dari asas itu sendiri, menurut C.W. Paton adalah : " $A$ principle is the broad reason, which lies at the base of a rule of law" (artinya : Asas ialah suatu alam pikiran yang dirumuskan secara luas dan yang

Terhadap pendapat tersebut, Mahadi mengkritisinya dengan menyatakan bahwa seolah-olah tiap norma hukum dapat dikembalikan kepada suatu asas, padahal dalam praktek terdapat norma-norma hukum yang tidak dapat ditelusuri bagaimana bunyi asas yang mendasarinya, semisal : norma hukum positif dalam bidang lalu-lintas, yang menyuruh pemakai jalan umum mempergunakan bagian kiri dari jalan itu. Dengan demikian norma hukum ini sulit dicarikan asasnya, tetapi kalau ia sudah menjadi norma hukum maka norma hukum itu sendirilah yang berfungsi sebagai asas.

Berbeda pandangan dengan pendapat tersebut, Jazim Hamidi menyatakan pendapatnya bahwa asas hukum merupakan bentuk awal pancaran normatif dari suatu filsafat hidup dan sekaligus merupakan nilai-nilai etik yang hidup dalam pergaulan masyarakat (Jazim Hamidi, 1996;54). Pendapatnya ini bersandar pada pendapat Moh. Koesnoe yang mendefinisikan asas, "sebagai bentuk awal pancaran normatif dari suatu filsafat hidup sebagai suatu instruksi untuk bagaimana memandang dan selanjutnya seharusnya menangani suatu lingkup persoalan-persoalan kehidupan". Bilamana lingkup persoalan itu persoalan hukum, maka asas itu Administrasi Negara) 
disebut “asas hukum” (Jazim Hamidi, 1996;50).

Lebih lanjut Jazim Hamidi menyimpulkan, asas hukum merupakan abstraksi dari norma-norma hukum, sedangkan norma hukum merupakan konkretisasi dari asas-asas hukum dalam bentuk peraturan hukum konkret (pasalpasal). Jadi, dapat dikatakan asas hukum pada dasarnya bersifat tidak tertulis, ketika asas tersebut dibentuk secara tertulis dalam suatu peraturan maka sudah menjadi norma hukum.

Secara lebih sederhana lagi, Ateng Syafrudin membedakan antara asas dan norma tersebut sebagai berikut (Ateng Syafrudin, 1994; 64-65). Asas merupakan; (1)Dasar pemikiran yang umum dan abstrak; (2)Ide atau konsep; (3)Tidak mempunyai sanksi norma merupakan: (a)aturan yang konkret; (b) penjabaran dari ide; (c)mempunyai sanksi.

Adapun pengertian norma menurut W.J.S. Poerwadarminta (W.J.S. Poerwadarminta, 2002;678) adalah ukuran (untuk menentukan sesuatu). Terlihat disini arti dari norma sangatlah sumir. Lain halnya dengan pendapat dari Hommes yang merumuskan pengertian norma dengan : "de op menselijke vormgeving aan beginselen rustende regels, die toepasselijk zijn op vrije, menselijke gedragingen dan sebagainya...". Maksud dari rumusan ini, norma adalah suatu aturan. Aturan tersebut berdasarkan pada suatu asas dan aturan diturunkan dari asas dalam suatu bentuk kalimat bahasa yang sedemikian rupa, sehingga aturan tersebut mempunyai arti bagi manusia dalam melakukan tindakan -tindakannya. Dengan kata lain, norma adalah suatu rumusan untuk dipakai oleh manusia dalam tingkah lakunya, selain itu pula norma dapat juga dinamakan aturan (Mahadi, 2003;124125; bandingkan Arief Sidharta, 2002;1-7).

Ciri-ciri khas dari norma hukum dibandingkan dengan norma-norma lainnya menurut Rosjidi Ranggawidjaja adalah (Rosjidi Ranggawidjaja, 1998;23-24): (1)Adanya paksaan dari luar yang berwujud ancaman hukum bagi pelanggarnya (biasanya berupa sanksi fisik yang dapat dipaksakan oleh alat negara); (2)bersifat umum, yaitu berlaku bagi siapa saja.

Menurut Rosjidi Ranggawidjaja pula, norma hukum ini diperlukan keberadaannya karena (Rosjidi Ranggawidjaja, 1998;24): (1)Tidak semua kepentingan atau tata tertib telah dilindungi atau diatur oleh ketiga norma tadi (agama, kesusilaan, dan kesopanan). Misalnya norma etika tidak mengatur hal-hal tentang gaji, lalu-lintas, pajak, pencatatan, perkawinan, dsb; (2)Sanksisanksi pelanggaran terhadap normanorma etika bersifat psychis, sangat abstrak; sedangkan sanksi terhadap 
pelanggaran norma hukum bersifat physik, dan nyata (kongkrit); (3)Sifat memaksanya sangat jelas dan dapat dipaksakan oleh alat negara (pemerintah), sedangkan norma etika tidak dapat dipaksakana oleh pemerintah (hanya berupa dorongan dari dalam diri pribadi manusia).

Kaitan asas-asas dan normanorma dengan perbuatan melanggar hukum oleh badan atau pejabat administrasi negara adalah pelanggaran hukum yang dimaksud melanggar ketentuan asas-asas atau norma-norma hukum publik. Pengertian asas-asas hukum publik ini menurut penulis adalah asas hukum publik secara umum. Sebagaimana penulis pahami, dalam hukum publik ada beberapa asas yang sering dikemukakan oleh para pakar hukum, diantaranya asas-asas umum pemerintahan yang baik (algemene beginselen van behorlijk bestuur atau the general principles of good administration) dalam hukum administrasi dan asas-asas hukum nasional dalam hukum publik pada umumnya.

Makna asas-asas hukum publik yang pertama atau asas-asas umum pemerintahan yang baik (AAUPB) adalah “.....asas-asas hukum tidak tertulis yang harus diperhatikan oleh badan atau pejabat administrasi negara dalam melakukan tindakan hukum yang akan dinilai kemudian oleh hakim administrasi" (sebagaimana Olden Bidara mengutip pandangan dari F.H. Van der Burg dan G.J.M. Cartigny dalam Olden Bidara, 1994;80).

Karena AAUPB ini merupakan asas hukum, maka AAUPB bukan merupakan kecenderungan etis dan bukan pula merupakan kecenderungan moral bagi pejabat administrasi yang menjalankan roda pemerintahan. Dikatakan demikian karena menurut S.F. Marbun, etika sebagai moralitas fokusnya adalah hukum, sedangkan moral pejabat administrasi negara fokusnya adalah pada karakter dan sifatsifat pejabat administrasi negara tersebut secara individual yang tidak terdapat di dalam peraturan-peraturan hukum. Artinya, hanya ditujukan kepada sikap batin pejabat administrasi negara untuk memiliki budi pekerti yang luhur, memiliki rasa malu, rasa bersalah dan lain-lain. Sanksinya, hanya bersifat intern dengan mengandalkan pada iktikad baik, kesadaran etis dan nilainilai moral pejabat administrasi negara tadi. Dengan kata lain, AAUPB ditegaskan adalah bagian dari hukum karena arahannya ditujukan kepada sikap lahir badan atau pejabat administrasi negara dengan disertai adanya beban hak dan kewajiban yang bersifat memaksa dan sanksi yang tegas serta konkrit bagi yang melanggarnya (S.F. Marbun, 2001;5657). 
Selain itu, AAUPB ditinjau dari perspektif filsafat hukum dapat dikatakan menyangkut kehidupan yang bersifat ekstern dari pejabat administrasi karena lebih cenderung sebagai penjabaran dari suatu perjanjian yang dapat diserahkan atau dipindahkan kepada pejabat administrasi lainnya, sehingga arahannya lebih ditujukan kepada kehidupan yang bersifat ekstern. Jadi menurut S.F. Marbun (S.F. Marbun, 2001;58-59), AAUPB salah satu fungsinya adalah : sebagai arahan atau patokan bagi pelaksanaan wewenang administrasi negara untuk memberikan dan menentukan batas-batas manakah yang harus diperhatikan oleh suatu jabatan umum secara hukum, maka kita harus berorientasi kepada peraturan dan asas-asas tatanan hukum, karena hanya dengan patokan-patokan hukum tersebut kepatuhan terhadap batas-batas jabatan umum itu dapat dipaksakan, bukan kepada apa yang dapat diharapkan dari kesadaran dan keinsyafan pribadi pemegang jabatan tersebut.

AAUPB ini pada awalnya dikemukakan oleh Crince Le Roy, yang di Indonesia kemudian diadopsi dan dikembangkan oleh Kuntjoro Purbopranoto. Kuntjoro Purbopranoto mengutip tulisan Crince Le Roy, dan menambahkan pendapatnya sendiri sehingga menjadi tiga belas asas yang dikandung dalam AAUPB, yaitu

(Kuntjoro Purbopranoto, 1981;28-29; bandingkan Philipus Hadjon, dalam Paulus Effendie Lotulung, 1994;106; lihat pula S.F. Marbun, 2001;166): (1) Asas kepastian hukum (principle of legal security);(2)Asas keseimbangan (principle of proportionality);(3)Asas bertindak cermat (principle of carefullness); (4)Asas motivasi untuk setiap keputusan pejabat administrasi/ tata usaha negara (priciple of motivasion); (5)Asas tidak boleh mencampuradukan kewenangan (principle of non misuse of competence); (6)Asas-Asas kesamaan dalam mengambil keputusan (principle of equality); (7)Asas permainan yang layak (principle of fair play); (8)Asas keadilan atau kewajaran (principle of arbitrariness); (9)Asas menanggapi pengharapan yang wajar (principle of meeting reised expectation); (10)Asas meniadakan akibat-akibat suatu keputus-an yang batal (principle of undoing the consequence of unnulled decisision); (11)Asas perlindungan atas pandangan hidup (cara hidup) pribadi (principle of protecting the personal way of life); (12)Asas kebijaksanaan (principle of sapiently);(13)Asas penyelenggaraan kepentingan umum (principle of public service).

Ketiga belas asas di atas, yang murni berasal dari Crince Le Roy adalah asas-asas yang tersebut pada butir (4), (5), (6), (8), (9), (10), dan (11). Hal ini Administrasi Negara) 
pun dirangkumnya dari yurisprudensi peradilan biasa dan bukan dari peradilan administrasi negara, karena peradilan administrasi negara ketika itu baru berlaku di Belanda pada tahun 1976. Asas kepastian hukum: (1)asas keseimbangan; (2)asas bertindak cermat; (3)dan asas permainan yang layak; (7)berasal dari G.J. Wiarda. Selanjutnya asas kebijaksanaan (12) dan asas penyelenggaraan kepentingan umum (13), merupakan tambahan dari Kuntjoro Purbopranoto. Macam-macam asas yang termasuk dalam ruang lingkup "Algemene Beginselen van Berhoorlijk Bestuur" tersebut, kemudian oleh para pakar hukum administrasi negara di Belanda secara akademis dikelompokkan menjadi asas formal dan asas materiil. Menurut Van der Vlies, asasasas formal meliputi : asas tujuan yang jelas, asas organ/lembaga yang tepat, asas perlunya peraturan, asas dapat dilaksanakan, dan asas konsensus. Sedangkan asas-asas materiil meliputi : asas tentang terminologi dan sistematika yang benar, asas tentang dapat dikenali, asas perlakuan yang sama dalam hukum, asas kepastian hukum, dan asas pelaksanaan hukum sesuai keadaan individu (lihat Bagir Manan, 1992;1920).

Lebih lanjut mengenai AAUPB tersebut, Pasal 3 Undang-undang Nomor 28 Tahun 1999 Tentang Penyelenggara

Makna Perbuatan Hukum Publik Oleh Badan Atau Pejabat Administrasi Negara Yang Melanggar (suatu Tinjauan Yuridis Menurut Hukum Administrasi Negara)
Negara Yang Bersih dan Bebas dari Korupsi, Kolusi, dan Nepotisme telah menjadikan asas-asas hukum publik menjadi suatu norma hukum publik. Ketentuan dalam Pasal 3 itu menyatakan bahwa Asas-Asas Umum Penyelenggaraan Negara (AAUPN) meliputi: (1)Asas Kepastian Hukum; (2)Asas Tertib Penyelenggaraan Negara; (3)Asas Kepentingan Umum; (4)Asas Keterbukaan; (5)Asas Proporsional; (6)Asas Profesional; dan (7)Asas Akuntabilitas.

Ketujuh asas tersebut menurut Penjelasan Pasal 53 ayat (2) butir b Undang-undang Nomor 5 Tahun 1986 Jis Undang-Undang No. 9 Tahun 2004 dan Undang-undang Nomor 51 Tahun 2009 disebut sebagai AAUPB. Penulis tidak sepakat mengenai Pengertian AAUPB menurut undang-undang ini, karena pada dasarnya AAUPB bersifat tidak hanya tertulis dan tidak terikat dalam beberapa asas saja. Menurut penulis AAUPB sebagai hukum tidak tertulis tumbuh dan berkembang secara pesat karena sifatnya yang abstrak dan dinamis yang dapat berubah cepat mengikuti perkembangan nilai-nilai yang hidup dalam masyarakat dan administrasi negara.

Kelebihan ke tujuh asas ini bila dibandingkan dengan AAUPB yang dikemukakan oleh Crince Le Roy dan dikembangkan oleh Kuntjoro Purbopranoto, pada dasarnya ke tujuh asas tersebut merangkum dari ke tiga belas Agus Budi Susilo 
asas AAUPB, bahkan menurut penulis asas-asas umum penyelenggaraan negara ini bersifat lebih luas karena ada satu asas yang tidak ada dalam ke tiga belas AAUPB yaitu asas tertib penyelenggaraan negara dan asas akuntabilitas.

persamaan hak atas kesempatan kerja dan penghidupan yang layak; (9)Asas bahwa hukum mengendalikan struktur perekonomian; (10)Asas kemerdekaan berserikat dan mengeluarkan pikiran; (11)Asas persamaan hak dan kewajiban bela negara; (12)Asas persamaan hak untuk mendapat pendidikan dan pengajaran; (13)Asas wajib memajukan budaya bangsa; (14)Asas demokrasi ekonomi; (14)Asas perlindungan kepentingan ekonomi yang menguasai hajat hidup orang banyak; (15)Asas kemakmuran rakyat; (16)Asas perlindungan fakir miskin dan anak terlantar; (17)Asas kebebasan memilih agama.

Berdasarkan hasil seminar tersebut, fungsi Asas-asas Hukum Dasar itu adalah mengarahkan dan sebagai pangkal tolak bagi hukum positif dan melekatkan kekuatan hukum materiil pada norma-norma hukum. Berkenaan dengan asas-asas hukum ini pula, penulis melihat adanya kesamaan yang erat dengan makna konsep good governance. Keterkaitan ini dapat diketahui dengan memahami prinsip-prinsip utama dari good governance itu sendiri. Unsurunsur utama dari good governance pada

Tabel :

Perbandingan Antara Asas-Asas Umum Penyelenggaraan Negara Dengan AsasAsas Umum Pemerintahan Yang Baik

\begin{tabular}{|l|l|}
\hline $\begin{array}{l}\text { AAUPN UU No.28 Tahun 1999 } \\
\text { (menurut UU No. 5 Tahun 1986 Jis } \\
\begin{array}{l}\text { UU No.9 Tahun } 2004 \text { dn UU No. 51 } \\
\text { Tahun } 2009 \text { disebut AAUPB) }\end{array}\end{array}$ & $\begin{array}{l}\text { AAUPB menurut Crince Le Roy , G.J. } \\
\text { Wiarda, dan Kuntjoro Purbopranoto }\end{array}$ \\
\hline Asas kepastian hukum & $\begin{array}{l}\text { Asas kepastian hukum, Asas meniadakan } \\
\text { akibat-akibat suatu keputusan yang batal }\end{array}$ \\
\hline Asas tertib penyelenggaraan negara & Asas penyelenggaraan kepentingan umum \\
\hline Asas kepentingan umum & Asas menanggapi penghargaan yang wajar \\
\hline Asas keterbukaan & \\
\hline
\end{tabular}

Makna Perbuatan Hukum Publik Oleh Badan Atau Pejabat Administrasi Negara Yang Melanggar (suatu Tinjauan Yuridis Menurut Hukum 


\begin{tabular}{|l|l|}
\hline \multirow{2}{*}{ Asas proporsional } & $\begin{array}{l}\text { Asas keseimbangan, Asas kesamaan dalam } \\
\text { mengambil keputusan, Asas permainan } \\
\text { yang layak, Asas keadilan atau kewajaran, } \\
\text { Asas perlindungan atas pandangan hidup } \\
\text { pribadi, Asas kebijaksanaan. }\end{array}$ \\
\hline Asas professional & $\begin{array}{l}\text { Asas bertindak cermat, Asas motivasi untuk } \\
\text { setiap keputusan pejabat administrasi, Asas } \\
\text { tidak boleh mencampur adukan kewenangan }\end{array}$ \\
\cline { 1 - 1 } & \\
\hline Asas akuntabilitas & \\
\hline
\end{tabular}

Selain itu, dalam hukum publik dikenal juga asas-asas hukum nasional. Asas-asas ini artinya berlaku secara umum, terutama dalam lapangan hukum publik. Sebagaimana rumusan hasil Seminar Temu Kenal Cita Hukum dan Penerapan Asas-asas Hukum Nasional tanggal 22-24 Mei 1995 yang diadakan oleh BPHN di Jakarta, maka diperoleh kesimpulan bahwa dengan memperhatikan pula hasil Seminar BPHN Tahun 1989 Tentang Asas-asas Hukum Nasional, maka dapat diidentifikasi Asas-asas Hukum Dasar yang terkandung dalam UUD 1945 antara lain sebagai berikut: Dalam Pembukaan; (1)Asas Kebebasan yang berperikemanusiaan dan berperikeadilan; (2)Asas bahwa Indonesia negara pejuang; (3)Asas pengakuan atas Kekuasaan Tuhan Yang Maha Esa;
(4)Asas mengayomi bangsa dan tanah air; (5)Asas memajukan kesejahteraan umum; (6)Asas mencerdaskan kehidupan bangsa; (7)Asas ikut menertibkan dunia; (8)Asas negara Pancasila; (9)Asas kebebasan memeluk Agama; (10)Asas kemanusiaan yang adil dan beradab; (11) Asas Kebangsaan; (12)Asas Bhineka Tunggal Ika; (13)Asas musyawarah untuk mufakat; (14)Asas keadilan sosial.

Dalam Batang Tubuh (hanya dicantumkan beberapa pasal yang masih relevan digunakan pasca Amademen Batang Tubuh UUD 1945: (1)Asas negara kebangsaan; (2)Asas kedaulatan rakyat; (3)Asas negara kesatuan berbentuk republik; (4)Asas negara demokrasi perwakilan; (5)Asas negara konstitusional; (6)Asas kekeluargaan; (7)Asas persamaan kedudukan dalam hukum dan pemerintahan; (8)Asas 
intinya ada lima hal yaitu akuntabilitas (accountability), transparansi (transparancy), keterbukaan (openess), aturan hukum (rule of law), dan jaminan fairness atau a level playing field (perlakuan yang adil atau perlakuan kesetaraan).

Di samping makna pelanggaran hukum ini, menurut penulis pelanggaran terhadap hukum adat dan hukum kebiasaan yang dilakukan oleh badan atau pejabat administrasi negara dalam melakukan perbuatan hukum publik pun dapat dikatakan sebagai onrechtmatige overheidsdaad. Sebagai contoh adalah pemilikan tanah eenslibing (tanah menumpang di bantaran sungai) yang dalam hukum adat dapat dimiliki secara langsung oleh individu yang pertama mengolah tanah tersebut. Tetapi terkadang badan atau pejabat administrasi negara mengeluarkan beschikking tentang kepemilikan tanah tersebut kepada individu tertentu berdasar permohonan atau prosedur formal.

Meskipun pengertian hukum adat dan kebiasaan ini masih sangatlah luas, tetapi secara umum hukum adat dapat diberikan pengertian sebagai hukum Indonesia asli, yang tidak tertulis dan disana-sini mengandung unsur agama (Kesepakatan Hasil Seminar Hukum Adat dan Pembinaan Hukum Nasional yang diselenggarakan oleh BPHN bekerjasama dengan Fakultas
Hukum UGM tanggal 15-17 Januari 1975 di Yogyakarta, lihat Abdurrahman, 1988;100). Melalui hukum adat ini pula diharapkan selain melalui perundangundangan dan ilmu hukum, tetapi juga perlunya peran dari putusan hakim hendaknya dibina ke arah hukum nasional secara hati-hati (Abdurrahman, 1988;101; bandingkan Retnowulan Sutantio dan Iskandar Oeripkartawinata, 2002;168).

Berkenaan dengan hal tersebut, bila terjadi pertentangan antara undangundang dengan hukum adat hendaknya hakim memutus berdasarkan undangundang dengan bijaksana. Oleh karena itu, diperlukanlah hakim-hakim yang berorientasi pada pembinaan hukum nasional.

Pengertian hukum adat berbeda dengan apa yang disebut dengan hukum kebiasaan. Hukum kebiasaan menurut tinjauan hukum tidaklah mempunyai arti yang sama dengan hukum adat, karena menurut E. Utrecht dan Moh. Saleh Djindang, hukum kebiasaan ialah himpunan kaidah-kaidah yang biarpun tidak ditentukan oleh badan-badan perundang-undangan dalam suasana realitas di taati juga, karena orang sanggup menerima kaidah-kaidah itu sebagai hukum dan telah ternyata kaidah-kaidah tersebut dipertahankan oleh kekuatan-kekuatan kemasyarakatan 
yang tidak termasuk lingkungan badanbadan pemerintahan (E.Utrecht dan Moh. Saleh Djindang, 1983;109).

Jadi, dapatlah dikatakan bahwa ia mendapatkan sumbernya dari kebiasaankebiasaan, yaitu sepanjang ia merupakan perbuatan yang selalu (terus-menerus) dilakukan orang dan diterimanya sebagai suatu kemestian (opinio necessitatis) (Achmad Sanusi, $2002 ; 81$ ).

Hukum kebiasaan inipun dapat dibedakan dalam beberapa bagian, yaitu : hukum kebiasaan masyarakat, hukum kebiasaan-hakim (pengadilan), hukum kebiasaan golongan-golongan kemasyarakatan, dan hukum kebiasaan Internasional.

Setelah dikemukakan perbedaan tersebut, maka pada hakekatnya tidak ada suatu perbedaan struktural (atau strukturil) antara kebiasaan dan adat. Perbedaan antara keduanya hanyalah perbedaan asal-muasalnya. Sebagaimana telah disebutkan dalam hukum adat sebagian dari kaidah-kaidah yang terdapat di masyarakat berasal dari suatu sumber hukum formil yang dianggap sakral. Jadi asal-usul hukum adat bersifat agak sakral (suci) dan diantaranya berasal dari kehendak nenek-moyang, agama dan tradisi rakyat, seperti yang dipertahankan dalam keputusan penguasa adat. Adapun hukum kebiasaan, dipertahankan oleh para penguasa yang tidak termasuk lingkungan badan-badan perundang-undangan semacam DPR, DPRD, dan sebagian besarnya berasal dari hasil akulterasi "budaya timur" dan "budaya barat" yang belum diresepsi sebagai tradisi. Dengan kata lain, hukum kebiasaan ini karena berasal dari hubungan atau kontrak antara dua budaya yang berbeda, tetapi kemudian hukum kebiasaan ini dapat diresepsi atau diterima dalam hukum Indonesia nasional sebagai sesuatu yang asli (E. Utrecht dan Moh. Saleh Djindang, 1983;110-112).

Indikator-indikator penerimaan kebiasaan atau suatu perbuatan sehingga lahir hukum kebiasaan, yaitu (Penyajian Hasil Penelitian Tentang Peranan Hukum Kebiasaan Dalam Hukum Nasional, Badan Pembinaan Hukum Nasional, Departemen Kehakiman, Jakarta, 1992;226): (a)Penerimaan badan peradilan bahwa praktek-praktek tersebut sebagai dasar gugatan atau dasar untuk mengambil keputusan; (b)Penerimaan oleh doktrin atau teori hukum bahwa suatu praktek dipandang mempunyai sifat hukum; (c)Apabila suatu peraturan perundang-undangan mengakui atau menyatakan suatu praktek atau kebiasaan sebagai hukum; (d)Apabila anggota masyarakat-umum atau kelompok tertentu menerima suatu praktek atau kebiasaan sebagai sesuatu yang harus 
ditaati (imperatif).

Salah satu contoh keterkaitannya hukum kebiasaan ini dengan perbuatan melanggar hukum publik oleh badan atau pejabat administrasi negara adalah seseorang atau sekelompok orang yang menempati di suatu bidang tanah tanpa alas hak, ketika mereka diminta oleh pejabat Pemda untuk pindah dari tempat tersebut, maka mereka tidak diberi ganti rugi bahkan rumah atau bangunan lain yang mereka tempati dibongkar secara paksa. Padahal kalau melihat suatu hukum kebiasaan yang ada seseorang atau sekelompok orang tadi seharusnya tetap diberi ganti kerugian meskipun tidak mempunyai alas hak, karena mereka sudah menempati tanah tersebut sampai bertahun-tahun lamanya. Menurut hemat penulis, perbuatan badan atau pejabat administrasi negara yang melakukan pembongkaran secara paksa dan tidak memberikan ganti rugi yang layak dapat dikategorikan sebagai perbuatan melanggar hukum oleh badan atau pejabat administrasi negara terutama bila ditinjau dari sudut pandang nilai keadilan.

Selain macam-macam makna pelanggaran hukum tersebut, sangat relevan pula dikatakan terjadi suatu pelanggaran hukum bila perbuatan oleh badan atau pejabat administrasi negara itu bertentangan dengan Hak Asasi
Manusia (HAM). Hal ini berkenaan pula dengan pendapat Rukmana Amanwinata yang menyatakan (Rukmana Amanwinata, 1996;122):

"Dalam rangka menegakkan hukum itu, HAM dalam negara harus dijamin. Demikian pula, untuk menjamin penggunaan HAM tersebut, organ negara baik mengenai pembentukan maupun tugas-wewenangnya harus diatur oleh hukum. Oleh karenanya dalam suatu Negara Hukum harus ditegakkan dan dijamin legalitas dalam arti hukum dalam semua bentuknya".

Pengertian Hak Asasi Manusia ini, menurut Rochmat Soemitro ialah keseluruhan hak dan kebebasan setiap manusia yang diperlukan untuk melangsungkan hidupnya dan dilindungi oleh Undang-Undang Dasar terhadap perbuatan sewenang-wenang dari penguasa (Rochmat Soemitro, 1965;20) S.F.Marbun sependapat dengan Sunaryati Hartono, bahwa sifat aturan hukum yang diterapkan dalam Pengadilan Administrasi adalah mencakup HTN, HAN, dan Hukum Antar wewenang. Oleh karenanya untuk menguji keputusan administrasi yang termasuk onrechtmatige overheidsdaad, nilai-nilai HAM harus merupakan bagian dari penilaian yang dilakukan Pengadilan Administrasi. Padahal, jaminan HAM termasuk dalam ruang lingkup HTN; lihat : S.F.Marbun, 1988;30: bandingkan, Sunaryati 
Hartono, 1976;20).

Lebih lanjut menurutnya, hak asasi sudah ada pada manusia sejak ia dilahirkan dan tidak timbul dengan adanya UUD atau Konstitusi. Berangkat dari hal itulah maka hak asasi itu merupakan hak yang tidak dapat dipindahkan kepada orang lain (unalienable rights). Meskipun hak asasi manusia dilindungi oleh UUD 1945, tetapi tidak semua hak asasi yang dimiliki oleh manusia disebut dalam UUD 1945.

Di dalam UUD 1945 hak asasi yang disebut dan dilindungi ialah : (a) Hak untuk hidup serta berhak mempertahankan hidup dan kehidupannya (Pasal 28 A); (b)Hak melakukan perkawinan yang sah (Pasal 28 B ayat (1)); (c)Hak setiap anak atas kelangsungan hidup, tumbuh dan berkembang serta berhak atas perlindungan dari kekerasan dan diskriminasi (Pasal 28 B ayat (2)); (d) Hak untuk mengembangkan diri melaui pemenuhan kebutuhan dasarnya, seperti : mendapat pendidikan, memperoleh manfaatdari ilmu pengetahuan dan teknologi, seni dan budaya, demi meningkatkan kualitas hidupnya dan demi kesejahteraan umat manusia (Pasal $28 \mathrm{C}$ ayat (1)); (e)Hak untuk memajukan dirinya dalam memperjuangkan haknya secara kolektif untuk membangun masyarakat, bangsa, dan negaranya (Pasal $28 \mathrm{C}$ ayat (2)); (f)Hak atas peng- akuan, jaminan, perlindungan dan kepastian hukum yang adil serta perlakuan yang sama dihadapan hukum (Pasal 28 D ayat (1)); (g)Hak untuk bekerja serta mendapat imbalan dan perlakuan yang adil dan layak dalam hubungan kerja (Pasal 28 D ayat (2)); (h)Hak memperoleh kesempatan yang sama dalam pemerintahan (Pasal 28 D ayat (3)); (i)Hak atas status kewarganegaraan (Pasal 28 D ayat (4)); (j)Hak kebebasan memeluk agama dan beribadat menurut agamanya, memilih pendidikan dan pengajaran, memilih pekerjaan, memilih kewarganegaraan, memilih tempat tinggal di wilayah negara dan meninggalkannya serta berhak kembali (Pasal 28 E ayat (1)); (k)Hak atas kebebasan meyakini kepercayaan, menyatakan pikiran dan sikap sesuai dengan hati nuraninya (Pasal 28 E ayat (2)); (1)Hak atas kebebasan berserikat, berkumpul, dan mengeluarkan pendapat (Pasal $28 \mathrm{E}$ ayat (3)); (m)Hak berkomunikasi dan memperoleh informasi untuk mengembangkan pribadi dan lingkungan sosialnya (Pasal 28 F); (n)Hak atas perlindungan pribadi, keluarga, kehormatan, martabat, dan harta benda yang di bawah kekuasaannya, serta berhak atas rasa aman dan perlindungan dari ancaman ketakutan untuk berbuat atau tidak berbuat sesuatu yang merupakan hak asasi (Pasal 28 G ayat (1)); (o)Hak bebas 
dari penyiksaan atau perlakuan yang merendahkan derajat martabat manusia dan berhak memperoleh suaka politik dari negara lain (Pasal $28 \mathrm{G}$ ayat (2)); (p)Hak hidup sejahtera lahir dan batin, bertempat tinggal, dan mendapatkan lingkungan hidup yang baik dan sehat serta berhak memperoleh pelayanan kesehatan (Pasal $28 \mathrm{H}$ ayat (1)); (q)Hak mendapat kemudahan dan perlakuan khusus untuk memperoleh kesempatan dan manfaat yang sama guna mencapai persamaan dan keadilan (Pasal $28 \mathrm{H}$ ayat (2)); (r)Hak atas jaminan sosial yang memungkinkan pengembangan dirinya secara utuh sebagai manusia yang bermartabat (Pasal 28 H ayat (3)); (s)Hak mempunyai hak milik pribadi dan hak tersebut tidak boleh diambil alih secra sewenang-wenang oleh siapa pun (Pasal $28 \mathrm{H}$ ayat (4)); (t)Hak untuk hidup, hak untuk tidak disiksa, hak kemerdekaan pikiran dan hati nurani, hak beragama, hak untuk tidak diperbudak, hak untuk diakui sebagai pribadi di hadapan hukum, dan hak untuk tidak dituntut atas dasar hukum yang berlaku surut (Pasal 28 I ayat (1)); (u)Hak bebas dari perlakuan yang bersifat diskriminasi atas dasar apa pun dan berhak mendapatkan perlindungan terhadap perlakuan itu (Pasal 28 I ayat (2)); (v)Hak identitas budaya dan hak masyarakat tradisional dihormati selaras dengan perkembangan zaman dan peradaban (Pasal 28 I ayat (3)).

Hak-hak asasi tersebut dalam batas-batas tertentu harus dilindungi, karena besar sekali kemungkinan hakhak itu diabaikan atau dilanggar oleh badan atau pejabat administrasi negara dalam menjalankan tugas pemerintahannya. Sebagaimana diketahui, dengan banyaknya ikut campur tangan pemerintah dengan bermacam-macam urusan, tidak saja urusan yang berkenaan dengan hukum publik tetapi dalam perkembangannya juga yang bertalian dengan hukum privat terutama dalam bidang ekonomi-sosial.

Contoh keputusan yang menurut pihak Penggugat melanggar HAM adalah keputusan yang dikeluarkan oleh KPU terhadap K.H. Abdurrahman Wahid (Gusdur). Permasalahan yang muncul apakah keputusan yang ditetapkan itu merupakan beschikking? apakah dengan keluarnya keputusan tersebut bukan menjadi kewenangan pengadilan administrasi negara (PTUN), karena dianggap sesuai ketentuan Pasal 2 huruf g? selain itu, apakah kewenangan KPU mengeluarkan keputusan tersebut dalam rangka menjalankan urusan pemerintahan sebagaimana dimaksud Pasal 1 butir 8, sehingga KPU dapat dianggap sebagai Badan Administrasi Negara?. Untuk menjawab hal per- 
masalahan ini tentu banyak silang pendapat, tetapi penulis tetap menganggap bahwa keputusan yang dikeluarkan yang berisi penolakan K.H. Abdurrahkan Wahid (Gusdur) sebagai calon Presiden bersifat beschikking, karena disamping dalam rangka menjalankan urusan administratif pemerintahan juga sesuai kriteria dalam Pasal 1 butir 9. KPU dalam hal ini dapat disebut sebagai Badan Admnistrasi Negara. Keputusan yang dikeluarkannya pun termasuk dalam lapangan hukum administrasi negara yang bersifat konkrit, individual, dan final. Mengenai melanggar HAM atau tidaknya, itu tergantung dari proses selama dipersidangan nantinya dan bagaimana hakim administrasi negara menilai serta memutus perkara tersebut.

Memahami makna dari perbuatan melanggar hukum oleh badan atau pejabat administrasi negara ini pada dasarnya bertujuan agar terwujud suatu pemerintahan yang baik (good governance), pemerintah yang bersih (clean government), dan pada akhirnya menuju pada pemerintahan yang berwibawa. Maksudnya adalah dengan pemahaman suatu perbuatan badan atau pejabat administrasi negara yang melanggar hukum, maka warga masyarakat yang merasa hak-haknya dilanggar dapat melakukan upaya hukum sebagai bentuk dari perlindungan hukum melalui peradilan administrasi negara (PTUN) dan peradilan administrasi negara (PTUN) inilah termasuk salah satu komponen suatu perwujudan dari good governance dan clean government.

Good governance bertalian erat atau mempunyai hubungan interdependent dengan clean government, karena dalam tinjauan filosofis suatu pemerintahan yang baik (good governance) dengan sendirinya akan melahirkan pemerintah yang bersih (clean governmnent), atau dengan kata lain clean government merupakan prasyarat bagi proses suatu good gover nance.Meskipun demikian, kenyataannya sering ditemukan pemerintahan yang baik belum tentu merupakan pemerintahan yang bersih ( S.F. Marbun, 2001;275).

Perkara yang sudah diputus mengenai pelanggaran HAM ini adalah Perkara No.129/G/2001/PTUN-BDG antara Asep Setia Pujanegara dan Rela Susanti selaku Penggugat melawan Kepala Dinas Kependudukan dan Catatan Sipil Kabupaten Bandung selaku Tergugat. Perkara ini mengenai ditolaknya para Penggugat yang penganut agama kepercayaan untuk mencatatkan perkawinannya oleh Tergugat. Penolakan ini Penggugat dalam positanya menyebutkan bahwa Tergugat telah melanggar HAM, 
menurutnya dalam hukum positif tidak ada keharusan untuk memeluk suatu agama karena dalam konstitusi hanya menyebutkan "Negara berdasar atas Ketuhanan Yang Maha Esa" dan dalam Penjelasannya "Ayat ini menyatakan kepercayaan bangsa Indonesia terhadap Tuhan Yang Maha Esa", selain itu perkawinan mereka adalah merupakan perkawinan adat jadi yang berlaku adalah hukum adat yang sudah lama diterapkan dari sebelum masa penjajahan Belanda.

Gugatan Penggugat ini kemudian dibantah oleh Tergugat, menurutnya Penafsiran Pasal 2 ayat (2) UU No.1 Tahun 1974 Tentang Perkawinan adalah perkawinan yang telah dilangsungkan berdasarkan menurut tata cara agama bukan tata cara perkawinan berdasarkan adat maupun aliran Penghayat Kepercayaan. Istilah "kepercayaan" dalam pasal tersebut mengandung pengertian kepercayaan terhadap agamanya dalam menjalankan ibadat, jadi bukan suatu aliran kepercayaan sebagaimana dimaksud Penggugat.

Dalam hal ini, Majelis Hakim mempertimbangkannya dengan menafsirkan Pasal 2 ayat (1), yaitu Perkawinan Penggugat adalah sah karena dilangsungkan menurut hukum adat, dengan demikian maka Tergugat haruslah mencatatkan perkawinan mereka demi kepastian hukum. Selain itu negara harusnya menerima eksistensi penganut kepercayaan sebagai makhluk ciptaan Tuhan yang memerlukan kehidupan yang normal seperti yang dijalani oleh sesama manusia lainnya dan efek pshycologis dengan tidak dicatatnya perkawinan tersebut. Disamping itu sebagai pengamalan Pancasila, maka dengan terpeliharanya kerukunan antar umat beragama dan penganut Kepercayaan terhadap Tuhan Yang Maha Esa akan memperkukuh landasan spiritual, moral dan etik bagi pembangunan nasional. Berdasarkan pertimbangan hukum yang demikian inilah Majelis Hakim mengabulkan gugatan penggugat dan mewajibkan Tergugat untuk mencatatkan perkawinan Penggugat yang menganut aliran kepercayaan itu. Menariknya lagi adalah Putusan pengadilan administrasi negara (PTUN Bandung) tingkat pertama ini dikuatkan oleh pengadilan administrasi negara tingkat banding (PTTUN Jakarta), tetapi sampai dengan penulisan ini Kasasi (Mahkamah Agung) yang diajukan Tergugat belum diputus.

\section{PENUTUP}

Berdasarkan uraian baik secara teoritis maupun analisis yuridis diatas, menurut hemat penulis makna perbuatan melanggar hukum oleh badan atau 
pejabat administrasi negara dalam hukum administrasi negara adalah perbuatan hukum publik bersegi satu (vertikal) dan perbuatan hukum publik bersegi dua (horisontal) yang dilakukan oleh badan atau pejabat administrasi negara melanggar hukum berdasarkan putusan lembaga peradilan lain (diluar peradilan administrasi negara (PTUN)) yang sudah in kracht van gevijsde, yurisprudensi, asas-asas hukum publik baik asas-asas umum pemerintahan yang baik atau asas-asas umum penyelenggara -an negara maupun asas-asas hukum nasional, hukum kebiasaan atau hukum adat, dan hak asasi manusia. Dengan demikian untuk tertibnya teknis dan administrasi peradilan serta integrasi, effektifitas dan effisiensi penegakkan hukum administrasi negara kedepannya perlu direvisi Undang-undang Nomor 5 Tahun 1986 Jis Undang-undang Nomor 9 Tahun 2004 dan Undang-undang Nomor 51 Tahun 2009 Tentang PTUN, terutama mengenai kewenangan peradilan administrasi negara (PTUN) sesuai philosopisnya dalam menyelesaikan sengketa administrasi negara yaitu dengan menjadikan "perbuatan hukum publik oleh badan atau pejabat administrasi yang melanggar hukum" sebagai objek sengketa di peradilan administrasi negara (PTUN).

\section{DAFTAR PUSTAKA}

Abdurrahman, (1988). Perkembangan Pemikiran Tentang Pembinaan Hukum Nasional di Indonesia, Akademika Pressindo, Jakarta

Amanwinata, Rukmana, (1996). Pengaturan Dan Batas Implementasi Kemerdekaan Berserikat dan Berkumpul Dalam Pasal 28 UUD 1945, Disertasi Program Pasca sarjana Universitas Padjadjaran, Bandung

Astawa, I Gde Pantja, (2001). Hubungan Fungsional Antara Hukum Administrasi Negara Dengan Undang-Undang No.4 Tahun 1982 Tentang Ketentuan Pokok Pengelolaan Lingkungan Hidup dan Pelaksanaannya, dalam S.F. Marbun, et.al., Dimensi-Dimensi Hukum Administrasi Negara, UII Press, Yogyakarta

Atmosudirdjo, Prajudi, (1994). Hukum Administrasi Negara, Ghalia Indonesia, Jakarta

Bidara, Olden, (1994). Asas-Asas Umum Penyelenggaraan Pemerintahan Yang Layak Dalam Teori Dan Praktek Pemerintahan, Dalam Himpunan Makalah Asas-Asas Umum Pemerintahan Yang Baik (AAUPB), Penyusun Paulus Effendie Lotulung, Citra Aditya Bhakti, Bandung 
Hadjon, Philipus M. (1997). "Penyelesai -an Sengketa Tanah Melalu Peradilan Tata Usaha Negara", Yuridika No. 2\&3 Th. XII

Hamidi, Jazim, (1996). Penerapan Beberapa Asas Umum Penyelenggaraan Pemerintahan Yang Layak Oleh Hakim Administrasi, Tesis Program Pascasarjana Unpad, Bandung

Hartono, Sunaryati, (1976). Beberapa Pikiran Mengenai Suatu Peradilan Administrasi Negara di Indonesia, Binacipta, Jakarta

Mahadi, (2003). Falsafah Hukum : Suatu Pengantar, Alumni, Bandung

Manan, Bagir, (1992). Dasar-Dasar Perundang-undangan Indonesia, IND-HILL.CO, Jakarta

Marbun, S.F., Peradilan Tata Usaha Negara, Liberty, Yogyakarta, 1988.

(2001). Eksistensi Asas-Asas Umum Penyelenggaraan Pemerintahan Yang Layak dalam Menjelmakan Pemerintahan Yang Baik dan Bersih di Indonesia, Disertasi Program Pascasarjana Unpad, Bandung

Na'a, Suprin, (2003). Ruang Lingkup Materi Muatan (Het Onderwerp) Peraturan Daerah Profinsi Dan Kabupaten/Kota Dalam Rangka Penyelenggaraan Pemerintahan Daerah, Tesis Program Pasca sarjana Universitas Padjadjaran, Bandung
Purbopranoto, Kuntjoro,(1981). Beberapa Catatan Hukum Tata Pemerintahan dan Peradilan Administrasi Negara, Alumni, Bandung

Penyajian Hasil Penelitian Tentang Peranan Hukum Kebiasaan Dalam Hukum Nasional, Badan Pembinaan Hukum Nasional, Departemen Kehakiman, (1992). Jakarta

Poerwadarminta, W.J.S., (2002). Kamus Umum Bahasa Indonesia, Balai Pustaka, Jakarta

Ranggawidjaja, Rosjidi, (1998). Pengantar Ilmu Perundangundangan di Indonesia, Mandar Maju, Bandung

Sanusi, Achmad, (2002). Pengantar Ilmu Hukum dan Pengantar Tata Hukum Indonesia, Tarsito, Bandung

Siahaan, Lintong Oloan, (2000). Wewenang PTUN Menunda Berlakunya Keputusan Pemerintah, Tesis Universitas Indonesia, Jakarta

Sidharta, Arief, (2002). Hukum dan Logika, Alumni, Bandung

Syafrudin, Ateng, (1994). "Butir-butir Bahan Telaahan Tentang Asasasas Umum Pemerintahan Yang Layak Untuk Indonesia", Dimuat dalam Paulus Effendie Lotulung (Ed), Himpunan Makalah Asasasas Umum Pemerintahan Yang Baik, Citra Aditya Bakti, Bandung

Soejadi, (1999). Pancasila Sebagai Sumber Tertib Hukum Indonesia, 
Lukman Offset, Yogyakarta

Soemantri, Sri, (1995). Proses Perumusan Cita Hukum dan AsasAsas Hukum dalam Periode Tahun 1908 sampai dengan sekarang, Makalah disampaikan dalam Seminar untuk memperingati 50 Tahun Indonesia Merdeka, diselenggarakan oleh BPHN pada tanggal 22-24 Mei 1995, dipublikasikan dalam Majalah Hukum Nasional, BPHN, Jakarta

Soemitro, Rochmat, (1965). Masalah Peradilan Administrasi dalam Hukum Padjak di Indonesia, Eresco, Bandung

Sutantio, Retnowulan dan Iskandar Oeripkartawinata, (2002). Hukum Acara Perdata dalam Teori dan Praktek, Mandar Maju, Bandung

Utrecht, E. dan Moh. Saleh Djindang, (1983). Pengantar Dalam Hukum Indonesia, Ichtiar Baru, Jakarta

Wiriaatmadja, Rustini, (1992). Tolok Ukur dan Beberapa Alternatif Swastanisasi Badan Usaha Milik Negara dalam Ekonomi Indonesia yang berdasarkan Pancasila dan UUD 1945, Tesis Program Pasca sarjana Universitas Padjadjaran, Bandung

Undang-Undang Dasar 1945 